\title{
Miranda
}

Revue pluridisciplinaire du monde anglophone /

Multidisciplinary peer-reviewed journal on the English-

speaking world

15 | 2017

Lolita at 60 / Staging American Bodies

\section{"The Power of Emotion : A Conversation with Katherine Brook and Shonni Enelow"}

Conversation with Katherine Brook and Shonni Enelow

\section{Katherine Brook and Shonni Enelow}

\section{(2) OpenEdition}

\section{Journals}

Electronic version

URL: http://journals.openedition.org/miranda/11013

DOI: 10.4000/miranda.11013

ISSN: 2108-6559

\section{Publisher}

Université Toulouse - Jean Jaurès

\section{Electronic reference}

Katherine Brook and Shonni Enelow, "'The Power of Emotion : A Conversation with Katherine Brook and Shonni Enelow"'", Miranda [Online], 15 | 2017, Online since 06 October 2017, connection on 16 February 2021. URL: http://journals.openedition.org/miranda/11013 ; DOI: https://doi.org/10.4000/ miranda. 11013

This text was automatically generated on 16 February 2021.

\section{c) 89}

Miranda is licensed under a Creative Commons Attribution-NonCommercial-NoDerivatives 4.0 International License. 


\section{“The Power of Emotion : A Conversation with Katherine Brook and Shonni Enelow"}

Conversation with Katherine Brook and Shonni Enelow

Katherine Brook and Shonni Enelow

\section{Biographies of the Artists}

1 Katherine Brook is a director of new experimental plays and performance and makes original work collaboratively with her theatre company, Katherine Brook / Tele-Violet. Her work has been presented at various venues in New York City and beyond, including The Public Theater's Under the Radar Festival, The Provincetown Tennessee Williams Theatre Festival, Incubator Arts Project, Prelude NYC, and more. Brook has also worked as a creative producer at The Foundry Theatre, The Builders Association, and New York City Players. MFA, Carnegie Mellon School of Drama.

2 Shonni Enelow is a writer and critic and assistant professor of English at Fordham University. Her book, Method Acting and Its Discontents: On American Psycho-drama (Northwestern University Press, 2015), was the winner of the 2015-2016 George Jean Nathan Award for Dramatic Criticism. Other recent publications include essays and articles on theater and media, American film acting, literature and performance documentation, and race in realist performance.

Brook and Enelow's previous collaborations as director and dramaturge include a production of Tennessee Williams's Suddenly Last Summer at Carnegie Mellon University and an adaptation of Richard Boleslavsky's acting manual Acting: The First Six Lessons at NYU/Tisch's Experimental Theatre Wing. They both received BFAs in Theater from New York University's Tisch School of the Arts. 


\section{Discussion}

4 Katherine Brook, director, and Shonni Enelow, writer and dramaturge, have collaborated for the past several years on a project called The Power of Emotion, a theatrical investigation of emotion in performance that takes its title from a 1983 film by Alexander Kluge and includes a new music score by composer Taylor Brook, performed live by the TAK Ensemble. They presented a work-in-progress version of the piece at The Public Theater's Under the Radar Festival in the Incoming! Series in 2015, and will present a final version at Abrons Art Center in October 2017, in a coproduction with Mount Tremper Arts, called The Power of Emotion : The Apartment.

What follows has been compiled from several conversations between Brook and Enelow in July and August 2017, as they prepared for the rehearsal process for the Abrons Art Center production.

Shonni Enelow : Let's start basic : what do we think is the relationship between acting and emotion?

7 Katherine Brook: I think the theater is the play-place for dangerous and unusual emotional exploration. I feel that way about theater in general. But I think that theater often doesn't take the opportunity to explore emotion as much as it could. And when it does, it usually just reinforces ideas about emotion that already exist.

SE : For me, this thinking came specifically out of my research on Method acting. What initially interested me about Method acting was the emotional memory exercise : the weird centerpiece of this acting style that was at once exotic and hegemonic hegemonic in that a lot of its basic ideas are really ubiquitous in American acting, but exotic because the closer you look at them, the stranger they get. What I found interesting was that although the exercise is ostensibly about reproducing past emotions, real emotions, from the actor's life, what seemed to me that it was actually doing was producing a new, theatrical emotion in the moment. So for me that was a crucial idea. Emotions - in acting, and maybe in general - are generated by a theatrical relationship, the relationship between an actor and an spectator.

$\mathrm{KB}$ : I'm also very interested in the way the audience receives emotion - and in the distaste I often have when I see emotion on stage. I'm fascinated by that feeling of "too much." And I'm critical of the stripping away of emotion in a lot of contemporary theater that I think sanitizes it - and makes watching theater easier.

SE : The stripping away of emotion - that's a real trend in experimental theater.

$\mathrm{KB}$ : I think there's a visceral problem that a lot of people have when they deal with actors. I think actors can do things with emotion that are really ugly and disturbing and disgusting and offend our taste. And that's really interesting to me.

$\mathrm{SE}$ : We wanted to go against the prevailing trend of low-affect acting. Which is - I think you're right - a response to the disgust a lot of people in experimental theater feel about mainstream American acting and its ways of performing emotion.

$13 \mathrm{~KB}$ : You and I both have that distaste as well, though. So the question became, how do we engage with emotion in acting in some kind of different way? And that brings us to the Chashama workshop [a workshop in 2014]. We'd just finished working on Acting: The First Six Lessons at ETW [Experimental Theatre Wing]. Which taught me a lot about the history of Method acting and its pedagogy - how you got taught to do this thing. 
SE : That show was an adaptation of Richard Boleslavsky's primer on acting, the first book on Stanislavskian acting to be published in the U.S.

KB : In the workshops we'd done in 2013, we'd used and demented some of those Method exercises to try to stimulate actors imaginative emotions.

SE : We had one exercise where we asked actors to come up emotional memories of watching theater. They had to remember an experience of watching theater that gave them some kind of powerful emotion as spectators.

$\mathrm{KB}$ : That was a way to access -

$\mathrm{SE}:$ The mimetic part -

KB : - of an actor's emotional life. There was such variety. Alex Spieth [one of the actors] brought in the experience of watching what sounded like a terrible performance of Oedipus.

SE : I also remember someone brought in the experience of watching a production of Les Mis and being really moved by "Castle on a Cloud." And then we had another actor in the group act out the memory. It was a way to estrange the idea of emotional memory. And also to literalize the idea that emotional memories are not some kind of return to an authentic truth but always, when they're reproduced, theatrical. That's an important idea that's still a big part of the piece: the emotions happen in between people. And are generated by a relationship. Even when that relationship is with an imagined other.

KB : During the Chashama workshop, we used a different exercise we called "the color wheel." We were wondering what kind of language could we use for these emotions that didn't fit into the categories of emotion we already have in language. The colors were just stand-ins, a way of naming emotions that don't have names. But because colors are evocative and expressive to most people, it worked.

SE : We had actors develop their own color wheels of emotion - the main criteria was that the emotions they were expressing through the colors couldn't fit neatly into predetermined categories. And they could use gesture to access and articulate these emotions too.

$\mathrm{KB}$ : It gave the actors new palettes of emotion they could play with.

SE : And that you could play with as a director, instructing them to integrate them into scenes we were working on in various ways. This was also the workshop where I first brought in text. And by this time we were using the film [Alexander Kluge's The Power of Emotion]. So we were already interested in using music, and opera specifically.

KB : Right. The Kluge film was so mysterious to me - and still is in some ways because it's at once emotionally opaque and rich with big, stormy emotions. And it's clever and goofy too. One way it strikes this dissonance is by discussing opera and giving a sense of it happening in the background, but not using it as the expressive mode itself.

26 SE : The big idea in the film is that the opera was the power plant of the emotions in the nineteenth century, and cinema is the power plant of the emotions in the twentieth.

$\mathrm{KB}$ : I took the first part as an invitation to explore the possibilities of operatic acting as well as the manipulative possibilities of music in general. In that first workshop Taylor [Brook, the composer] brought in a selection of arias that were supposed to evoke particular emotions, and we experimented with how they affected actors and how they 
affected audience perception. It became clear that music would be a central part of this project, and Taylor wrote a score, inspired in part by opera, for the first public presentation of this piece at the Under the Radar Festival in 2015.

SE : In the Under the Radar version of the piece, we were working with big, operatic emotions, and I wanted to represent the idea of emotional contagion in the script. So I came up with a story about a cult leader who seduces an actress and gets her to burn down a building. It was supposed to be over-the-top and excessive, but also metatheatrical - in the sense that we were trying to reflect on how emotion is produced by actors on the stage - and stylistically it ended up kind of like Genet's The Maids. I think I was trying to match the intensity of Taylor's music. That was fun, but it wasn't the direction I wanted to take the script for this version that we're doing at Abrons. With this iteration, The Apartment, I became more interested in the second part of Kluge's idea : that cinema became the power plant of the emotions in the twentieth century. I don't think that's still true in the twenty-first - maybe it's social media now ? But it got me more interested in thinking about realism, and juxtaposing different forms of emotional performance. Realist versus operatic. This is the juxtaposition in Kluge's film. He intersperses scenes of opera and very abstract, expressionist montages with realist scenes that follow different cinematic genres, specifically crime genres.

$\mathrm{KB}$ : It was so spooky and serendipitous that I sat on the jury of an arson case last year. As soon as the case was over - I was on that jury for weeks - I called you to relay it all because the resonances with our artwork were so loud. And I guess you agreed...

SE : Yes, I ended up writing The Apartment around your experience, or my fantasy of your experience, as a juror. It had everything : the story was great, obviously, because it was about an intimate relationship that emotionally went haywire and became literally destructive - in the form of a fire, which was in our previous version of the piece. And it connected to opera: we were already using Wagner's Ring Cycle as an intertext, which ends with Brunhilde lighting a fire and riding into it on a horse. And it was a way to think about spectatorship, because you were a spectator as a juror and it's through your experience that we have access to the story - not directly, but through its retelling and reconstruction.

31 KB : And I was a participant in a way, too. I think that's part of what is so fascinating about crime stories - one's proximity to the crime, which as a juror feels very close, yet protected. I've thought about that experience a lot and it's influenced the work in many ways.

SE : To get back to acting and emotion : part of what's important to me is that we're not interested in thinking about performance in general - we're interested in acting. And the difference is that acting means playing character, in some way. Using pre-existing text that has some kind of other person in it. We weren't going down the road of a lot of avant-garde theater - we weren't thinking about $\mathrm{KB}$ : The essence of presence?

\section{$\mathrm{SE}$ : Right. I think this is why we kept using the word 'acting.'}

KB : The ongoing challenge for me is how to create performances with actors that are emotional and embodied, but not strictly bound to realism.

SE : But we in this project - and I think you in your work in general - are very interested in using the building blocks of realism, the elements of realist acting. We're 
not using the building blocks of Butoh. We're not using the building blocks of Meyerhold. We're using American realism. Apartment, is the way it is exploring realism. I think that has the potential to fulfill the possibilities of the project as a whole but it's a real challenge. I'm excited by the way we're opposing the uber-theatrical operatic performance to the trial, to these intimate, less explicitly performed scenes. We've circled back to the Kluge film with this new version. I hope our show provokes that same emotional alienation and intrigue that I find so mysterious in the film.

SE : I do want people to be both seduced by the emotions they're seeing the actors perform and also estranged from them and confused by them, in that Brechtian way. This is a piece about the ways that emotions rule our lives - the characters are very much guided by emotions in ways they themselves don't understand or accept - but also about the ways we perceive and take in, or don't take in, emotion as we watch theater. Without being too grandiose, I think this has a lot of relevance for what's going on in the U.S. today. Method acting teachers and practitioners, at least in the twentieth century, generally thought that emotional expression meant authentic communication between people and would lead to truth - this is sort of a basic idea in realism in general. But the opposite seems to be true today. Emotional expression of the kind we're seeing doesn't lead to communication at all. And part of the reason seems to be that it's generated by a theatrical feedback loop between a performer (Trump) and his spectators that's self-reinforcing and enclosed. We haven't been actively thinking about American politics as we work on this piece, but I do think we're trying to break open and investigate those feedback loops, when they work and when they don't.

\section{ABSTRACTS}

A conversation between director Katherine Brook and writer and dramaturge Shonni Enelow about their collaborative project, The Power of Emotion: The Apartment, premiering at Abrons Art Center (New York, NY) in October, 2017.

Echange entre la metteuse en scène Katherine Brook et l'auteur et dramaturge Shonni Enelow au sujet de leur collaboration autour de The Power of Emotion: The Apartment, présenté pour la première fois à l'Abrons Art Center (New York, NY) en octobre 2017.

Miranda, 15 | 2017 
INDEX

Mots-clés: théâtre américain, théâtre expérimental, méthodes de jeu, réalisme, opéra, film, la Méthode, mémoire affective, Wagner, fiction de détection

Subjects: Theater

Keywords: American theater, experimental theater, acting methods, realism, opera, film, Method acting, emotional memory, Wagner, crime stories

\section{AUTHORS}

\section{SHONNI ENELOW}

Assistant Professor of English

Fordham University

senelow@fordham.edu 